\title{
Molecular phylogeny of euglyphid testate amoebae (Cercozoa: Euglyphida) suggests transitions between marine supralittoral and freshwater/terrestrial environments are infrequent
}

\author{
Thierry J. Heger ${ }^{\text {a,b,c,d,e,*, Edward A.D. Mitchell a,b,c, Milcho Todorov }}{ }^{\mathrm{f}}$, Vassil Golemansky ${ }^{\mathrm{f}}$, Enrique Lara ${ }^{\mathrm{c}}$, \\ Brian S. Leander ${ }^{\mathrm{e}}$, Jan Pawlowski ${ }^{\mathrm{d}}$ \\ ${ }^{a}$ Ecosystem Boundaries Research Unit, Swiss Federal Institute for Forest, Snow and Landscape Research (WSL), CH-1015 Lausanne, Switzerland \\ ${ }^{\mathrm{b}}$ Environmental Engineering Institute, École Polytechnique Fédérale de Lausanne (EPFL), Station 2, CH-1015 Lausanne, Switzerland \\ ${ }^{\mathrm{c}}$ Institute of Biology, University of Neuchâtel, $\mathrm{CH}-2009$ Neuchâtel, Switzerland \\ ${ }^{\mathrm{d}}$ Department of Zoology and Animal Biology, University of Geneva, Sciences III, CH-1211 Geneva 4, Switzerland \\ ${ }^{\mathrm{e}}$ Departments of Zoology and Botany, University of British Columbia, Vancouver, BC, Canada V6T $1 Z 4$ \\ ${ }^{\mathrm{f}}$ Institute of Zoology, Bulgarian Academy of Sciences, 1000 Sofia, Bulgaria
}

\section{A R T I C L E I N F O}

\section{Article history:}

Received 24 June 2009

Revised 22 November 2009

Accepted 25 November 2009

Available online $\mathrm{xxxx}$

\section{Keywords:}

Cryptic species

Cyphoderia

Cyphoderiidae

Euglyphida

Freshwater

Marine supralittoral

Phylogeny

Protista

Rhizaria

SEM

SSU rRNA gene

Testate amoebae

\begin{abstract}
A B S T R A C T
Marine and freshwater ecosystems are fundamentally different regarding many biotic and abiotic factors. The physiological adaptations required for an organism to pass the salinity barrier are considerable. Many eukaryotic lineages are restricted to either freshwater or marine environments. Molecular phylogenetic analyses generally demonstrate that freshwater species and marine species segregate into different sub-clades, indicating that transitions between these two environments occur only rarely in the course of evolution. It is, however, unclear if the transitions between freshwater and environments characterized by highly variable salinities, such as the marine supralittoral zone, are also infrequent. Here, we use testate amoebae within the Euglyphida to assess the phylogenetic interrelationships between marine supralittoral and freshwater taxa. Euglyphid testate amoebae are mainly present in freshwater habitats but also occur in marine supralittoral environments. Accordingly, we generated and analyzed partial SSU rRNA gene sequences from 49 new marine/supralittoral and freshwater Cyphoderiidae sequences, 20 sequences of the Paulinellidae, Trinematidae, Assulinidae, and Euglyphidae families as well as 21 GenBank sequences of unidentified taxa derived from environmental PCR surveys. Both the molecular and morphological data suggest that the diversity of Cyphoderiidae is strongly underestimated. The results of our phylogenetic analyses demonstrated that marine supralittoral and freshwater euglyphid testate amoeba species are segregated into distinct sub-clades, suggesting that transitions between these two habitats occurred only infrequently.
\end{abstract}

(c) 2009 Elsevier Inc. All rights reserved.

\section{Introduction}

The biotic and abiotic factors in marine and freshwater ecosystems differ considerably and impose physiological constraints on organisms that pass through this salinity barrier. As a consequence, the taxonomic compositions of the communities encountered in both environments are quite divergent. Some major eukaryotic lineages are restricted to either marine or freshwater environments. For example, radiolarians, echinoderms, most

\footnotetext{
* Corresponding author. Address: Wetlands Research Group, Ecosystem Boundaries Research Unit, WSL, Swiss Federal Institute for Forest, Snow and Landscape Research, Station 2, CH-1015 Lausanne, Switzerland. Fax: +4121693 3913.

E-mail addresses: thierry.heger@epfl.ch (T.J. Heger), edward.mitchell@unine.ch (E.A.D. Mitchell), mtodorov@zoology.bas.bg (M. Todorov), golemansky@zoology.bas.bg (V. Golemansky), enrique.lara@unine.ch (E. Lara), bleander@interchange.ubc.ca (B.S. Leander), Jan.Pawlowski@unige.ch (J. Pawlowski).
}

foraminiferans, most haptophytes, and pelagophytes are marine, whereas no representative of the Mycetozoa has ever been found in saltwater. In contrast, other eukaryote lineages occur in both marine and freshwater/terrestrial habitats. For instance, cryptophytes, diatoms and dinoflagellates are abundant in both environments. But even within these groups, phylogenetic studies have indicated a limited number of marine/freshwater transitions, suggesting that such events are rare in the evolutionary history of different lineages (von der Heyden and Cavalier-Smith, 2005; Alverson et al., 2007; Cavalier-Smith and von der Heyden, 2007; Logares et al., 2007; Shalchian-Tabrizi et al., 2008; Cavalier-Smith, 2009). Likewise, even though at the morphospecies level several microeukaryotic lineages appear to have wide salinity ranges, molecular phylogenies show that they are uncommon (Koch and Ekelund, 2005; Finlay et al., 2006; Scheckenbach et al., 2006; Bass et al., 2007). 
The order Euglyphida Copeland, 1956, is a group of testate amoebae with filamentous pseudopodia that build self-secreted silica tests. Euglyphids are currently divided into five families: the Assulinidae, Euglyphidae, Trinematidae, Paulinellidae and Cyphoderiidae (Meisterfeld, 2002; Adl et al., 2005; Lara et al., 2007). These organisms were considered as exclusive inhabitants of soil and freshwater habitats up to the second part of the 20th century. Early reports of Euglyphida from subsurface waters of the Pacific Ocean (Wailes, 1927) were interpreted as imports from continental freshwaters. Since then, Euglyphida were more intensively investigated in marine supralittoral environments and today, more than 50 species were described from the marine supralittoral of the Black Sea and other marine habitats of the World (Golemansky, 1974, 2007; Ogden and Couteaux, 1989; Chardez, 1991; Golemansky and Todorov, 1999). While the Assulinidae, Euglyphidae and Trinematidae have been found almost exclusively in terrestrial or freshwater habitats (for simplicity hereafter referred to as freshwater), the Cyphoderiidae and the Paulinellidae are found also in the marine supralittoral zone (Meisterfeld, 2002).

The marine supralittoral environment is characterized by variable salinity values, which can fluctuate relatively rapidly between typical seawater to less than $10 \%$ (Todorov and Golemansky, 2007; Todorov et al., 2009). Thus, organisms inhabiting such an environment must face huge selective pressure to adapt to these harsh conditions. The Cyphoderiidae are one of the few microeukaryotic groups that have successfully colonised both environments. Therefore, they represent an excellent model group to study the impact of salinity in eukaryotic cell evolution.

The current Euglyphida taxonomy is largely based on shell characters. Shells are composed of secreted plates which often differ in shape, size and arrangement among species (Meisterfeld, 2002). However, morphological data alone are often unreliable for testing hypotheses of colonization processes because such characters can be subject to convergent evolution during the marine to freshwater transition (or vice versa) (Lee and Bell, 1999).

In order to overcome these current limitations, a detailed phylogenetic study of freshwater and marine supralittoral Euglyphida, combining both molecular and morphological characters, is required. In this work, we inferred the molecular phylogenetic relationships between marine supralittoral and freshwater members of the Cyphoderiidae using SSU rRNA gene sequences and documented the morphology of isolated species with scanning electron microscopy. We hypothesised that only two separate marine and freshwater phylogenetic clades existed in the Cyphoderiidae.

\section{Materials and methods}

\subsection{Sampling and species identifications}

We sampled cyphoderiidae species from freshwater aquatic mosses and from subsurface waters of freshwater and marine sand beaches at five Bulgarian, two Canadian and three Swiss sites (Table 1). Following the most recent taxonomic revision (Chardez, 1991; Meisterfeld, 2002; Golemansky and Todorov, 2004, 2006; Todorov et al., 2009), we identified six Cyphoderia, one Corythionella and one Pseudocorythion morphotypes among a total of 15 populations (Table 1). The morphology of seven of these 15 populations was recently investigated by Todorov et al. (2009). This previous study revealed significant morphological differences among Cyphoderia ampulla populations from Moiry $(\mathrm{CH})$, Rhodopes (BG) and Vitosha (BG), suggesting more than one taxon within the C. ampulla morphospecies. This morphological study however called for a complementary molecular study.

We used the classification proposed in the Illustrated Guide to the Protozoa (Meisterfeld, 2002). Thus, Corythionella and Pseudoc- orythion species belong to the Cyphoderiidae family although they were initially described as members of the Psammonobiotidae family (Golemansky, 1970; Valkanov, 1970; Chardez, 1991). In this paper we use the terms "Euglyphid testate amoebae", or "euglyphids" to refer to the Euglyphida sensu stricto.

\subsection{Testate amoebae isolation for DNA extractions and scanning electronic imaging}

The testate amoebae were isolated by sieving and back sieving. With the exception of Cyphoderia cf. compressa, all samples from the marine sand beaches were incubated between 4 and 8 weeks in the laboratory, at about $20^{\circ} \mathrm{C}$ prior to the isolation. For each DNA preparation, between 5 and 100 individuals were isolated individually under light microscope using fine diameter glass pipettes. Cells were washed by transferring them three times into distilled water. A guanidine thiocyanate protocol was used to extract DNA (Chomczynski and Sacchi, 1987). The shell ultrastructure of selected individuals from each populations, excepting Cyphoderia ampulla from Dragichevo, C. ampulla from Sofia and C. cf. compressa from Tsawassen, were investigated by scanning electron microscopy (SEM) by Todorov et al. (2009) or in the present study (Figs. 1 and 2). For SEM, testate amoeba shells were mounted on stubs and kept for 2 weeks in a desiccator. The shells were coated with gold in a vacuum coating unit and observed either with a JEOL JSM5510 microscope at a tension of $10 \mathrm{kV}$ or with a PHILIPS XL30 FEG microscope at a tension of $5 \mathrm{kV}$.

\subsection{SSU rDNA amplification and sequencing}

The 3' terminal fragment (708-765 bp) of the SSU rRNA gene and a selected number of near full-length (1697-1795 bp) portions of this gene were amplified by nested polymerase chain reaction (PCR) with the universal eukaryotic primers in the first PCR (Table 2) and then using a specific Cyphoderiidae primer and a universal eukaryotic primer in the second PCR (Table 2). The PCR cycling profile was the same for all PCRs: $30 \mathrm{~s}$ initial denaturation step $\left(95^{\circ} \mathrm{C}\right)$, followed by 40 cycles of $95^{\circ} \mathrm{C}$ for $30 \mathrm{~s}, 50^{\circ} \mathrm{C}$ for $30 \mathrm{~s}$, and $72{ }^{\circ} \mathrm{C}$ for $90 \mathrm{~s}$ and a final extension at $72^{\circ} \mathrm{C}$ for $10 \mathrm{~min}$. The $\mathrm{PCR}$ products were purified using the High Pure PCR Purification Kit (Roche Diagnostics) and cloned in TOPO TA cloning Kit (Invitrogen) or sequenced directly. Sequencing was carried out using a BigDye197 Terminator Cycle Sequencing Ready Reaction Kit (Applied Biosystems) and analysed either with an ABI-3130xl or a 3730S 48-capillary DNA sequencer (Applied Biosystems). Sequences are deposited in GenBank with the Accession Numbers GU228850-GU228898.

\subsection{Dataset constructions}

Three data sets were used for phylogenetic analyses. The first included 50 short Cyphoderiidae SSU rDNA sequences (682 bp). The second comprises 43 near full-length SSU rDNA Euglyphida sequences (1461 bp) and the third included 43 Euglyphida as well as 21 environmental sequences $(1461 \mathrm{bp})$. Publicly available SSU rDNA environmental sequences from the Euglyphida were downloaded from GenBank through the taxonomy web site at National Center for Biotechnology Information (http://www.ncbi.nlm.nih.gov). The sequences were found by BLAST searches using query sequences from all main Euglyphida families (i.e., Assulinidae, Cyphoderiidae, Euglyphidae, Paulinellidae and Trinematidae). These searches were finalized on October 20th 2009. Euglyphid sequences were manually fitted to a general alignment of eukaryotic SSU rRNA gene sequences (Berney and Pawlowski, 2004) using the BIOEDIT 7.0.9 sequence alignment editor (Hall, 1999). This last alignment was based on a universal model of eukaryotic SSU rRNA secondary structure (Van de Peer et al., 2000). Ambiguously 
Table 1

List of the Cyphoderiidae morphotaxa analysed and sampling locations.

\begin{tabular}{|c|c|c|c|c|c|c|c|c|c|c|}
\hline \multirow[t]{2}{*}{ Taxa } & \multirow[t]{2}{*}{ Habitat } & \multirow[t]{2}{*}{ Sampling location } & \multirow[t]{2}{*}{ Country } & \multirow[t]{2}{*}{$\begin{array}{l}\text { Sampling } \\
\text { date }\end{array}$} & \multicolumn{2}{|c|}{ Co-ordinates } & \multirow[t]{2}{*}{$\begin{array}{l}\text { Altitude } \\
(\mathrm{m})\end{array}$} & \multicolumn{2}{|c|}{$\begin{array}{l}\text { Number of SSU rDNA } \\
\text { sequences ( } \mathrm{nb} \text { of } \\
\text { extractions) }\end{array}$} & \multirow{2}{*}{$\begin{array}{l}\text { PCR products } \\
\text { cloned }(C) \text { or } \\
\text { sequenced } \\
\text { directly (SD) }\end{array}$} \\
\hline & & & & & & & & $\begin{array}{l}\text { Short } \\
\text { fragment }\end{array}$ & $\begin{array}{l}\text { Long } \\
\text { fragment }\end{array}$ & \\
\hline $\begin{array}{l}\text { Corythionella } \\
\text { minima }\end{array}$ & $\begin{array}{l}\text { Marine } \\
\text { supralittoral }\end{array}$ & $\begin{array}{l}\text { Underground waters of } \\
\text { marine sand beach, Galata, } \\
\text { Black Sea }\end{array}$ & Bulgaria & July 2006 & $43^{\circ} 10^{\prime} \mathrm{N}$ & $27^{\circ} 56^{\prime} \mathrm{E}$ & 0 & $2(1)$ & $1(1)$ & (C) \\
\hline $\begin{array}{l}\text { Cyphoderia } \\
\text { amphoralis }\end{array}$ & Freshwater & Sphagnum mosses, Rila & Bulgaria & $\begin{array}{l}\text { August } \\
2005\end{array}$ & $42^{\circ} 12^{\prime} \mathrm{N}$ & $23^{\circ} 22^{\prime} \mathrm{E}$ & 1960 & $3(3)$ & $1(1)$ & (SD) \\
\hline $\begin{array}{r}\text { Cyphoderia } \\
\text { ampulla }\end{array}$ & Freshwater & Aquatic mosses, Moiry & Switzerland & July 2006 & $46^{\circ} 08^{\prime} \mathrm{N}$ & $07^{\circ} 34^{\prime} \mathrm{E}$ & 2310 & $3(2)$ & $2(2)$ & $(\mathrm{SD})$ \\
\hline $\begin{array}{r}\text { Cyphoderia } \\
\text { ampulla }\end{array}$ & Freshwater & $\begin{array}{l}\text { Sphagnum mosses, } \\
\text { Dragichevo }\end{array}$ & Bulgaria & $\begin{array}{l}\text { August } \\
2006\end{array}$ & $42^{\circ} 36^{\prime} \mathrm{N}$ & $23^{\circ} 09^{\prime} \mathrm{E}$ & 960 & $3(2)$ & $1(1)$ & (SD) \\
\hline $\begin{array}{r}\text { Cyphoderia } \\
\text { ampulla }\end{array}$ & Freshwater & Sphagnum mosses, Rhodopes & Bulgaria & July 2005 & $41^{\circ} 59^{\prime} \mathrm{N}$ & $24^{\circ} 10^{\prime} \mathrm{E}$ & 1109 & $6(2)$ & $1(1)$ & (SD) \\
\hline $\begin{array}{r}\text { Cyphoderia } \\
\text { ampulla }\end{array}$ & Freshwater & $\begin{array}{l}\text { Sphagnum mosses, Sofia, } \\
\text { South Park }\end{array}$ & Bulgaria & $\begin{array}{l}\text { August } \\
2006\end{array}$ & $42^{\circ} 39^{\prime} \mathrm{N}$ & $23^{\circ} 18^{\prime} \mathrm{E}$ & 610 & $2(2)$ & - & (SD) \\
\hline $\begin{array}{r}\text { Cyphoderia } \\
\text { ampulla }\end{array}$ & Freshwater & Sphagnum mosses, Vitosha & Bulgaria & $\begin{array}{l}\text { August } \\
2006\end{array}$ & $42^{\circ} 36^{\prime} \mathrm{N}$ & $23^{\circ} 17^{\prime} \mathrm{E}$ & 1850 & $2(2)$ & $1(1)$ & (SD) \\
\hline $\begin{array}{r}\text { Cyphoderia } \\
\text { ampulla }\end{array}$ & Freshwater & $\begin{array}{l}\text { Underground waters of } \\
\text { freshwater sand beach, Lake } \\
\text { Geneva, St-Sulpice }\end{array}$ & Switzerland & May 2008 & $46^{\circ} 30^{\prime} \mathrm{N}$ & $06^{\circ} 32^{\prime} \mathrm{E}$ & 375 & $3(3)$ & $3(3)$ & (SD) \\
\hline $\begin{array}{c}\text { Cyphoderia } \mathrm{cf} . \\
\text { compressa }\end{array}$ & $\begin{array}{l}\text { Marine } \\
\text { supralittoral }\end{array}$ & $\begin{array}{l}\text { Underground waters of } \\
\text { marine supralittoral sand } \\
\text { beach, Tsawassen, Pacific } \\
\text { Ocean }\end{array}$ & Canada & $\begin{array}{l}\text { October } \\
2008\end{array}$ & $49^{\circ} 01^{\prime} \mathrm{N}$ & $123^{\circ} 06^{\prime}$ & 0 & $1(1)$ & $1(1)$ & (SD) \\
\hline $\begin{array}{l}\text { Cyphoderia } \\
\text { compressa }\end{array}$ & $\begin{array}{l}\text { Marine } \\
\text { supralittoral }\end{array}$ & $\begin{array}{l}\text { Underground waters of } \\
\text { marine supralittoral sand } \\
\text { beach, Galata, Black Sea }\end{array}$ & Bulgaria & July 2006 & $43^{\circ} 10^{\prime} \mathrm{N}$ & $27^{\circ} 56^{\prime} \mathrm{E}$ & 0 & $11(3)$ & $3(3)$ & (C) \\
\hline $\begin{array}{r}\text { Cyphoderia } \\
\text { littoralis }\end{array}$ & $\begin{array}{l}\text { Marine } \\
\text { supralittoral }\end{array}$ & $\begin{array}{l}\text { Underground waters of } \\
\text { marine supralittoral sand } \\
\text { beach, Galata, Black Sea }\end{array}$ & Bulgaria & July 2006 & $43^{\circ} 10^{\prime} \mathrm{N}$ & $27^{\circ} 56^{\prime} \mathrm{E}$ & 0 & $3(1)$ & $1(1)$ & (C) \\
\hline $\begin{array}{l}\text { Cyphoderia } \\
\text { major }\end{array}$ & Freshwater & Sphagnum mosses, Rila & Bulgaria & $\begin{array}{l}\text { August } \\
2005\end{array}$ & $42^{\circ} 12^{\prime} \mathrm{N}$ & $23^{\circ} 22^{\prime} \mathrm{E}$ & 1960 & $2(1)$ & $1(1)$ & (SD) \\
\hline $\begin{array}{r}\text { Cyphoderia } \\
\text { ampulla }\end{array}$ & Freshwater & $\begin{array}{l}\text { Aquatic mosses, Cape } \\
\text { Breton, Nova Scotia }\end{array}$ & Canada & July 2008 & $46^{\circ} 48^{\prime} \mathrm{N}$ & $60^{\circ} 49^{\prime} \mathrm{W}$ & 236 & $2(1)$ & $1(1)$ & (SD) \\
\hline $\begin{array}{l}\text { Cyphoderia } \\
\text { trochus ssp. } \\
\text { palustris }\end{array}$ & Freshwater & Wet mosses, Marchairuz & Switzerland & $\begin{array}{l}\text { February } \\
2007 \text { and } \\
\text { May } 2008\end{array}$ & $46^{\circ} 33^{\prime} \mathrm{N}$ & $06^{\circ} 14^{\prime} \mathrm{E}$ & 1359 & $4(4)$ & $4(4)$ & (SD) \\
\hline $\begin{array}{l}\text { Pseudocorythion } \\
\text { acutum }\end{array}$ & $\begin{array}{l}\text { Marine } \\
\text { supralittoral }\end{array}$ & $\begin{array}{l}\text { Underground waters of } \\
\text { marine supralittoral sand } \\
\text { beach, Galata, Black Sea }\end{array}$ & Bulgaria & May 2008 & $43^{\circ} 10^{\prime} \mathrm{N}$ & $27^{\circ} 56^{\prime} \mathrm{E}$ & 0 & $2(2)$ & $2(2)$ & (SD) \\
\hline
\end{tabular}

aligned regions, gaps, highly divergent sequences (e.g., Tracheleuglypha dentata and three environmental sequences) and two environmental sequences (AY620296 and AY620297) with unclear affiliation within the Euglyphida were excluded from the analyses. Additionally, only one environmental sequence was selected when several identical or nearly identical environmental sequences were available in GenBank. Corythionella minima and Pseudocorythion acutum, which branch as a sister group to the Cyphoderia genus (Fig. 3), were used as outgroups in the first tree. The second and the third trees were rooted with six thaumatomonad sequences, the inferred sister group of the Euglyphida (Adl et al., 2005).

\subsection{Phylogenetic analyses}

Phylogenetic analyses were performed with maximum likelihood using RAxML (Stamatakis et al., 2008) and Bayesian inference methods using MrBayes v. 3.1.2 (Huelsenbeck and Ronquist, 2001). The MrAIC program (Nylander, 2004) identified the general-timereversible model with invariable sites and gamma distribution $(\mathrm{GTR}+\mathrm{G})$ as the most appropriate model of sequence evolution for the first and third data sets and the general-time-reversible model with invariable sites and gamma distribution (GTR + I + G) as the most appropriate model for the second data set. For the three data sets, maximum likelihood analyses were run for 1000 replicates and the most likely tree chosen from those runs. Boot- strap proportions (BS) were estimated under the same conditions for 1000 pseudoreplicates. Bayesian analyses were performed for the second and third data sets only. Three simultaneous Markov chains were run up to 10 million generations from a random starting tree. Trees were sampled every 10 generations. The first 250,000 trees were discarded as the burn in after checking that the chains had converged. The resultant trees were used to calculate the posterior probabilities (PP) for each node. The convergence of the Markov chains were graphically estimated by plotting the sample values versus the iteration values as well as by using diagnostics criteria produced by the "sump" command in MrBayes $(\mathrm{PSRF}=1.00)$. Bayesian analyses were run through the Bioportal web-based service platform for phylogenomic analysis at the University of Oslo (www.bioportal.uio.no).

\section{Results}

\subsection{Phylogenetic trees based on Euglyphida SSU rRNA sequences}

We first performed a phylogenetic analysis based on a short SSU rDNA alignment including 50 sequences ( $682 \mathrm{bp}$ ) from marine supralittoral and freshwater Cyphoderiidae populations (Table 1). Extractions from the same population always gave almost identical sequences (between $99.5 \%$ and $100 \%$ identity), and revealed 14 distinct clades. However, the relationships among clades were not well 

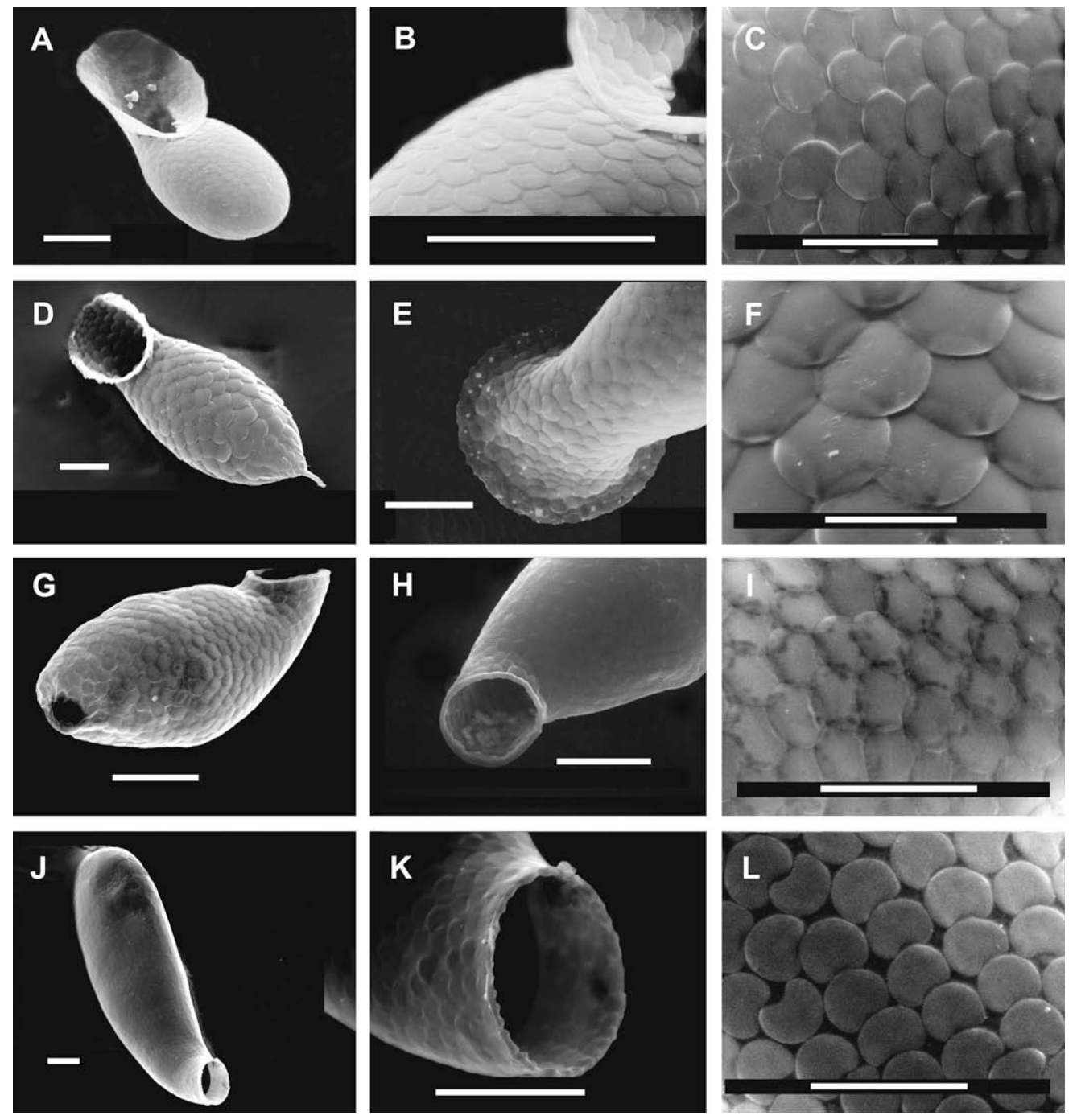

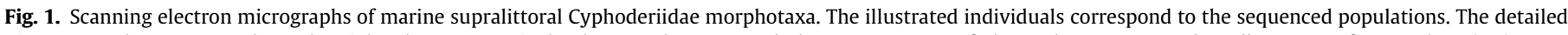

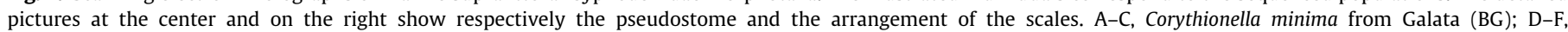

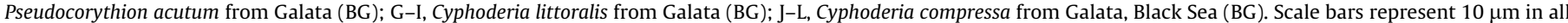
pictures excepted for the detailed pictures of arrangement of the scales (C, F, I and L) scale bars represent $5 \mu \mathrm{m}$ ( $\mathrm{G}, \mathrm{H}$ and I from Todorov et al., 2009).

resolved, showing no consistent groupings across Bayesian and maximum likelihood analyses (Supplementary material Fig. 1). In order to increase the phylogenetic signal and to clarify the relationships between these clades, we analysed a longer SSU rDNA data set (1461 bp) including 24 Cyphoderiidae sequences and 19 sequences of the Paulinellidae, Trinematidae, Assulinidae, and Euglyphidae families (Fig. 3). At least one sequence of each of 14 Cyphoderiidae clades mentioned above was represented in this analysis.

Phylogenetic trees inferred from Bayesian and maximum likelihood approaches showed quite similar topologies (Fig. 3). Marine supralittoral and freshwater Euglyphida species were segregated into three major clades (Fig. 3). The first clade included freshwater testate amoebae of the Trinematidae, Assulinidae and the Euglyphidae families, the second well-supported clade was constituted of marine and non-marine Cyphoderiidae phylotypes while the two freshwater Paulinella chromatophora sequences formed a third well-supported clade. The Paulinellidae clade branched as a sister group to the Cyphoderiidae clade with moderate statistical support (97\% BS and 0.84 PP). Within the Cyphoderiidae clade, the marine supralittoral Pseudocorythion acutum, Corythionella minima and Cyphoderia littoralis phylotypes had an early diverging position relative to the other sequences in the analysis (Fig. 1A-I and Fig 3).
The phylogenetic relationships among the marine supralittoral species $C$. compressa (Fig. 1J-L) and $C$. cf. compressa and the two separated freshwater sub-clades were moderately supported (Fig. 3). The highly supported freshwater sub-clades 1 (97\% BS and $1.00 \mathrm{PP}$ ) comprised Cyphoderia amphoralis, C. trochus ssp. palustris and C. ampulla from Cape Breton, Rhodopes, Vitosha and Dragichevo - this clade was composed of isolates having a shell built of overlapping or slightly overlapping scales (Fig. 2A-O); and the highly supported subclade 2 (100\% BS and 1.00 PP) comprised freshwater lineages $C$. major and $C$. ampulla from Lake Geneva (Switzerland), Aachen (Germany), and Moiry (Switzerland) - this clade was composed of isolates having a shell built of non-overlapping scales (Fig. 2P-X). The morphospecies C. ampulla was thus a polyphyletic entity including five distinct phylotypes (sequence divergence $>1 \%$ among the five $C$. ampulla clusters), (Supplementary material Fig. 1, Fig. 2D-L and P-U, Table 1).

\subsection{Phylogenetic trees inferred from euglyphid and environmental SSU rRNA sequences}

In order to evaluate the phylogenetic relationships between marine supralittoral and freshwater Euglyphida species more 

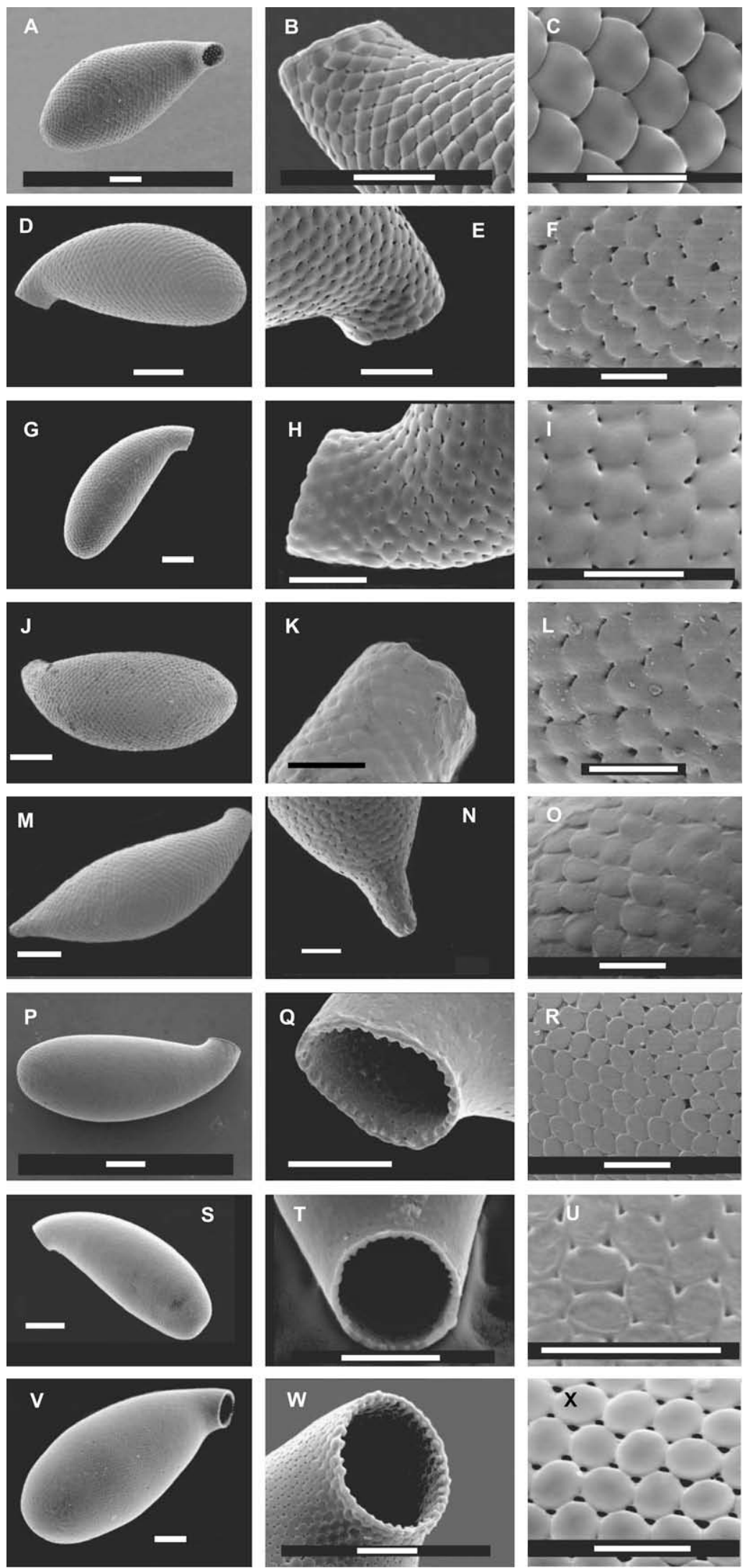

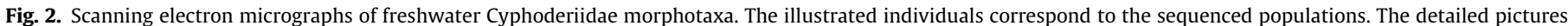

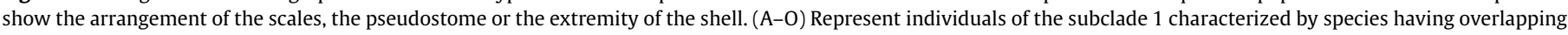

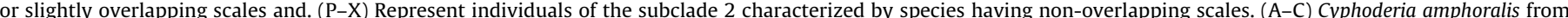

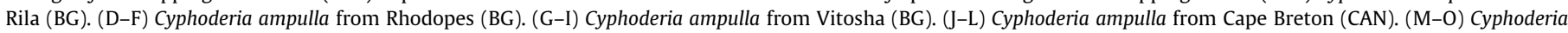

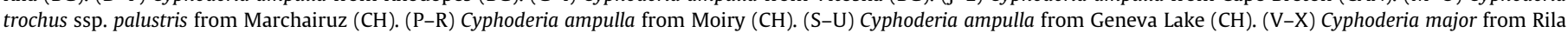
(BG). Scale bars on the left, at the center and on the right correspond respectively to 20,10 and $5 \mu \mathrm{m}$ (pictures A, B, P-R and V-X from Todorov et al., 2009).

Please cite this article in press as: Heger, T.J., et al. Molecular phylogeny of euglyphid testate amoebae (Cercozoa: Euglyphida) suggests transitions between marine supralittoral and freshwater/terrestrial environments are infrequent. Mol. Phylogenet. Evol. (2010), doi:10.1016/j.ympev.2009.11.023 
Table 2

Sequences of SSU and COI primers used in this study.

\begin{tabular}{|c|c|c|c|c|}
\hline Name & Specificity & Sequence $\left(5^{\prime}-3^{\prime}\right)$ & Direction & Location (on E. rotunda X77692) \\
\hline A10S1 & Most eukaryote & CTCAAAGATTAAGCCATGC & Forward & 35 \\
\hline CercoR & Most cercozoa & GGTCGAGGTCTCGTTCGTTAACGG & Reverse & 1331 \\
\hline Cyphrevb $^{a}$ & Most Cyphoderiidae & CACATAATCTGCCAATGGAGTCG & Reverse & 1078 \\
\hline Eugl ba & Most Cyphoderiidae & CGACTCCATTGGCA & Forward & 1078 \\
\hline s12.2 & Universal eukaryotic primer & GATCAGATACCGTCGTAGTC & Forward & 1013 \\
\hline sB & Universal eukaryotic primer & TGATCCTTCTGCAGGTTCACCTAC & Reverse & 1781 \\
\hline SSUcypho $^{\mathrm{a}}$ & Most Cyphoderiidae & CTATACCGACTATCGATCAGTG & Forward & 1044 \\
\hline
\end{tabular}

a Primers newly designed in this study.

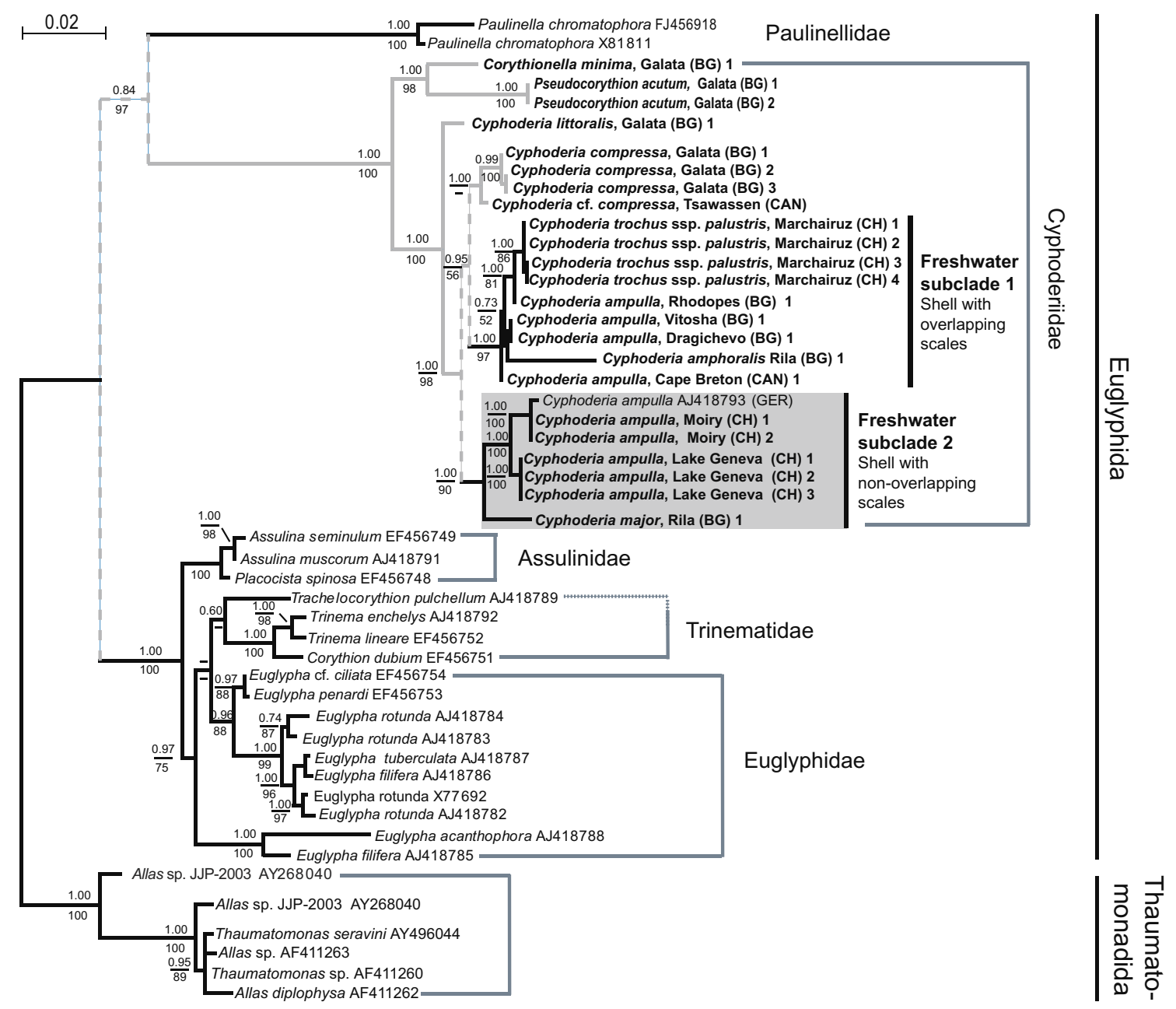

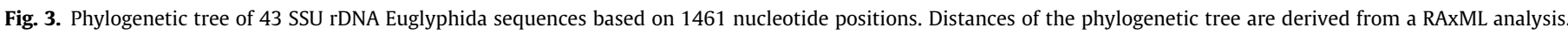

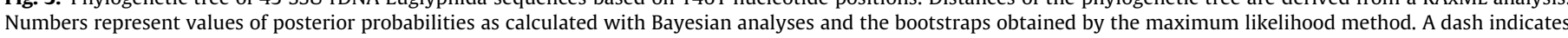

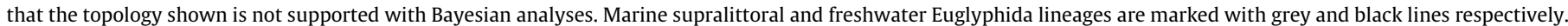
Data obtained in this study are denoted in bold. The tree was rooted with six thaumatomonads.

broadly, we analyzed an additional dataset (1461 bp) including 21 short environmental sequences assigned to the Euglyphida (Fig. 4). The validity of the two major groups inferred in the former analysis was confirmed (100\% BS and $1.00 \mathrm{PP})$. Ten environmental sequences derived from soil samples branched within the clade formed by the families Trinematidae, Assulinidae and the Euglyphidae (more specifically inside Trinematidae). Five marine environmental sequences and the freshwater Paulinella chromatophora were closely related and formed a third robust monophyletic group (Paulinellidae clade, Fig. 4). Two environmental sequences from the marine supralittoral environment (AY620307 and AY620315) branched at the base of all other Cyphoderiidae sequences. Two additional marine supralittoral environmental sequences
(AY620326 and AY620325) branched among the marine supralittoral Cyphoderiidae sequences and the soil sequence AY620259 branched within the freshwater Cyphoderiidae subclade 1. Supralittoral environmental sequence AY620293 and C. compressa (sensu lato) formed a sister group to the freshwater subclade 1 .

\section{Discussion}

\subsection{Marine supralittoral-freshwater transitions}

Several studies have suggested that the physiochemical differences between marine and freshwaters environments represent a strong barrier that cannot be crossed by most eukaryotic species 


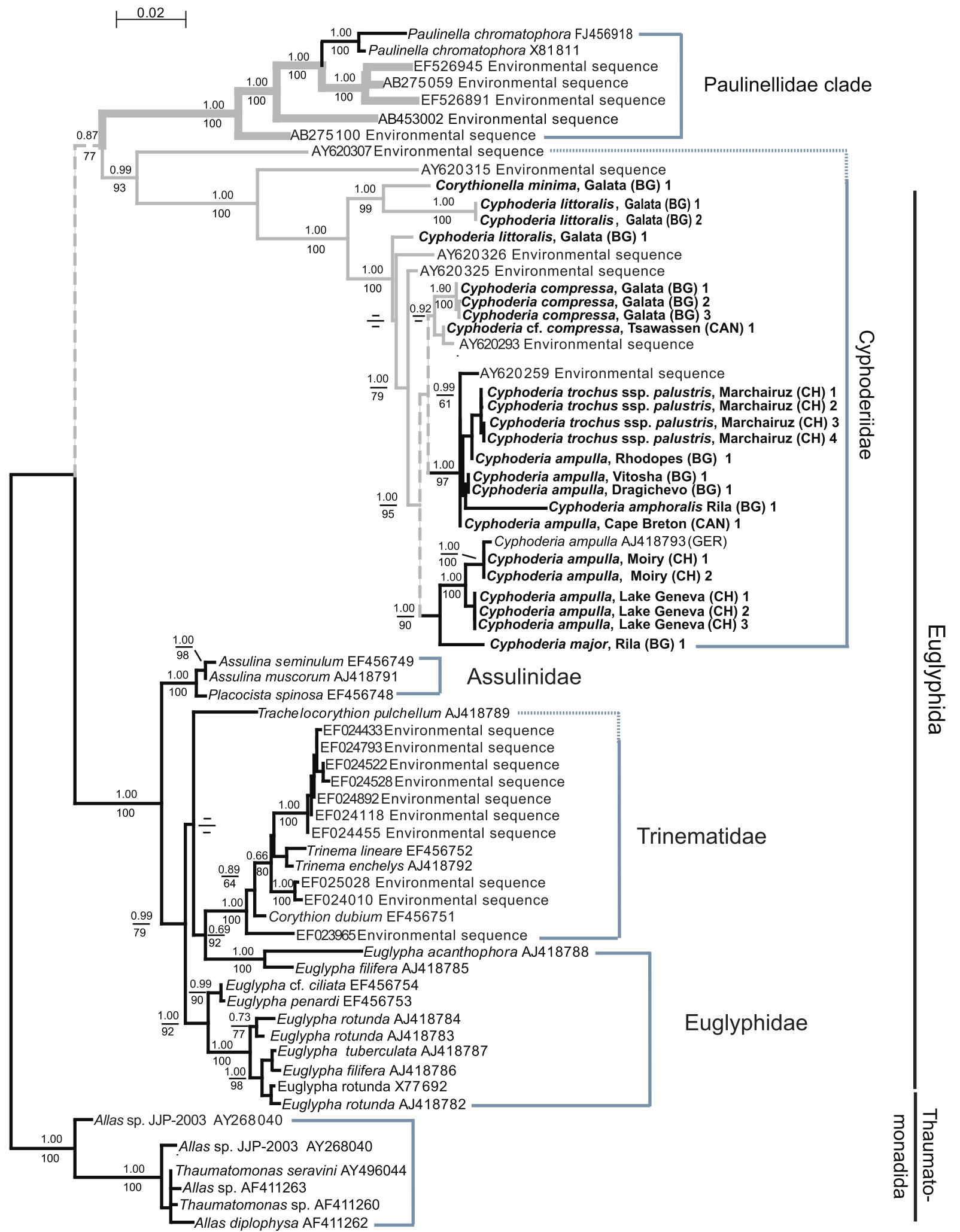

Fig. 4. Phylogenetic tree of 43 Euglyphida and 21 environmental SSU rDNA sequences based on 1461 nucleotide positions. The best-fit model selected in MrAIC (Nylander) was the general-time-reversible model with gamma distribution $(G T R+I+G)$. Numbers represent values of posterior probabilities as calculated with Bayesian analyses and the bootstraps obtained by the maximum likelihood method. A dash indicates that the bootstraps values are lower than 50. Marine and freshwater Euglyphida lineages are marked with grey and black lines, respectively. Marine, marine supralittoral and freshwater Euglyphida lineages are marked with large grey, grey and black lines, respectively. Lines with unclear marine or freshwater origin are indicated with dashed lines. Data obtained in this study are denoted in bold. The tree was rooted with six thaumatomonads. 
(Alverson et al., 2007; Logares et al., 2007, 2009; Shalchian-Tabrizi et al., 2008; Cavalier-Smith, 2009). As an extension of this research, our aim was to study the molecular phylogenetic relationships between marine supralittoral and freshwater cyphoderiid testate amoebae as a model system for inferring the frequency of habitat transitions in microbial eukaryotes.

The phylogenetic analyses of isolated euglyphids and related environmental sequences from GenBank demonstrated the existence of three highly divergent clades. The first clade comprised one Paulinella chromatophora sequence isolated from freshwater and five marine environmental sequences of unknown morphology (Fig. 4). Previous species descriptions based on morphology also suggest that the only truly marine species within the Euglyphida belong to the genus Paulinella (Wulff, 1916; Vors, 1993; Hannah et al., 1996; Nicholls, 2009). Paulinella chromatophora was reported from both freshwater habitats and brackish waters (Pankow, 1982; Yoon et al., 2009). It is unclear whether the P. chromatophora morphospecies corresponds to a single euryhaline species or to different phylotypes having potentially distinct salinity requirements. This genus alone, therefore, represents another interesting subject for studying marine-freshwater transitions.

The second clade comprises freshwater and marine supralittoral sequences within the Cyphoderiidae. The third clade comprises the freshwater Trinematidae, Assulinidae and Euglyphidae. Neither studies based on comparative morphology nor molecular phylogenetic data have yet convincingly demonstrated the existence of any marine or marine supralittoral species within these three families, which includes more than $80 \%$ of the total number of described Euglyphida taxa (Meisterfeld, 2002). Indeed, the only specimens within these three families reported in marine environments were mostly observed in the Baltic Sea where the salinity is very low (less than 4.5\%o) and in most cases it was unclear if these reports concerned living individuals or empty shells.

The concordance between the morphology-based taxonomy and molecular phylogenetic data at the genus/major morphotype level suggests that a more extensive phylogeny will demonstrate only few additional transitions between marine supralittoral and freshwater environments within the Euglyphida.

The phylogenetic clustering of the Cyphoderiidae in our analyses suggests that transitions between marine supralittoral and freshwater habitats are infrequent and occurred only twice in this clade. Freshwater Cyphoderia species emerge as two monophyletic sub-clades (Figs. 3 and 4). However, the phylogenetic relationships among the two freshwater sub-clades and C. compressa (sensu lato) are not strongly supported. We therefore cannot exclude that all freshwater phylotypes constitute a single clade. Such a scenario would suggest only one transition between marine supralittoral and freshwater habitats. This hypothesis would be consistent with the morphological characteristics of the two freshwater subclades. Freshwater morphotaxa are characterized by circular cross-sections while $C$. compressa (sensu lato) are characterized by laterally compressed shells. Clarifying the phylogenetic relationships among the two freshwater sub-clades and the C. compressa (sensu lato) would require sequencing additional genes and/or including potential missing organisms in our phylogenies.

The Cyphoderiidae contains five genera: Corythionella, Cyphoderia, Messemvriella, Pseudocorythion and Schaudinnula; Nicholls (2003b) transferred Campascus into the Psammonobiotidae. The genera Pseudocorythion and Corythionella, which are each represented in our phylogeny by only one taxon, comprise four and nine species, respectively. While Pseudocorythion comprises only marine supralittoral species (Meisterfeld, 2002), two among 10 Corythionella species occur in freshwater (Nicholls, 2003a, 2005, 2007, 2009). This suggests one more transition between marine supralittoral and freshwater environments among the Corythionella genus. Based on morphology, we expect the two marine supralittoral
Messemvriella species to be closely related to Pseudocorythion and Corythionella because they share several distinct morphological features. However, Messemvriella species differ from Pseudocorythion by the lack of a caudal horn and from Corythionella by the circular transverse section and the arrangement of the scales (Golemansky, 1973; Meisterfeld, 2002). Additionally, it would be very interesting to determine the phylogenetic position of the only species of Schaudinnula. By contrast to all other Cyphoderiidae species, the shell of this very rare and poorly documented freshwater species is composed of irregularly overlapping scales (Schönborn, 1965; Meisterfeld, 2002).

\subsection{Other potential factors}

The marine supralittoral is a specific environment characterized by fluctuating salinity. Several macroorganisms such as some littorinid snails (Judge et al., 2009) or microorganisms such as some Cyphoderiidae species are restricted to this environment (Golemansky, 2007). However, given the fact that data on marine microeukaryotic diversity remain quite limited with of the exception of the pelagic euphotic zone, we can not completely exclude the presence of Cyphoderiidae species in benthic or pelagic marine environments (Cuvelier et al., 2008; Epstein and Lopez-Garcia, 2008). Detecting Cyphoderiidae species in truly marine environments would require a taxon-specific primer approach as successfully used by Bass and Cavalier-Smith (2004) Bass et al. (2007) or Lara et al. (2009) for revealing poorly explored protist lineages in environmental DNA surveys.

Besides salinity, numerous other factors (e.g., pH, oxygen content, organic versus mineral substrate) may influence protist communities and restrict some species to specific habitats (Fallu and Pienitz, 1999; Booth et al., 2008). In this study, substrates generally differ between marine and freshwater Cyphoderiidae samples (Table 1). However, substrates differences are unlikely to account for the infrequent transition between marine supralittoral and freshwater habitats. The freshwater Cyphoderia ampulla isolated from sandy habitat branches among other freshwater Cyphoderia species isolated from aquatic mosses and not within marine supralittoral Cyphoderia species isolated from a sandy habitat. Several freshwater and marine supralittoral species of unrelated taxonomical groups, such as Pseudocorythion acutum or Corythionella minima, are characterized by large apertural collars. This morphological feature is considered an adaptation to the substrate (i.e., to life on sand grains rather than to freshwater or marine environments per se (Meisterfeld, 2002).

\subsection{Cryptic cyphoderiid diversity}

The existence of cryptic or pseudo-cryptic species may have high relevance in explaining disjunctive geographic distribution patterns or functional niches. Among microeukaryotes, such as within the Foraminifera or within Bacillariophyceae, cryptic species are relatively abundant (de Vargas et al., 1999; Pawlowski and Holzmann, 2002; Beszteri et al., 2005; Darling and Wade, 2008). Within the Euglyphida, cryptic species were so far reported only from two Euglypha morphospecies (Wylezich et al., 2002).

Our molecular phylogenetic data revealed the existence of cryptic species within the Cyphoderiidae. The environmental sequence data suggests the existence of two marine supralittoral species from Canada (AY620325 and AY620326) closely related to C. littoralis and therefore of the existence of undescribed diversity within this taxon. The morphospecies Cyphoderia ampulla is represented by five different phylotypes distributed throughout two distinct freshwater sub-clades in our trees and is therefore a polyphyletic taxon. The phylotypes of these two sub-clades are characterized by distinct arrangements of the scales as revealed by SEM analyses. 
The first one includes $C$. amphoralis, $C$. trochus ssp. palustris and $C$. ampulla from Cape Breton, Rhodopes, Vitosha and Dragichevo and is composed of isolates having a shell built of overlapping scales. C. ampulla sequences from Vitosha and Dragichevo are almost identical to each other (sequence divergence $<1 \%$ ) but differ from $C$. ampulla from Cape Breton and Rhodopes. The second freshwater subclade (Fig. 2), represented by $C$. major and $C$. ampulla from Geneva Lake (Switzerland), Aachen (Germany), and Moiry (Swiss Alps), is characterized by specimens having a shell composed of non-overlapping scales. The Cyphoderia ampulla sequence from Moiry is almost identical to the C. ampulla from Germany which was the only Cyphoderiidae sequence previously available in GenBank.

These results are consistent with a previous biometrical study that suggested the existence of at least two different taxa within C. ampulla morphotype (Todorov et al., 2009). In our study, different $C$. ampulla phylotypes were isolated from distinct ecological habitats such as underground water of a sandy beach on Lake Geneva, aquatic mosses in an Alpine stream or Sphagnum mosses of an oligotrophic peatbog (Table 1). Because C. ampulla morphotypes includes cryptic species having probably different ecological requirements, the Cyphoderia ampulla morphotype should be used with extreme caution for biogeographical, paleoecological or ecological studies. The taxonomic status of some Cyphoderiidae species should be revised. Therefore, a DNA barcoding approach coupled with traditional taxonomic tools would be very useful for clarifying the cyphoderiid taxonomy. The cryptic and pseudo-cryptic diversity revealed by this study and the one of Todorov et al. (2009) suggest that the total diversity of genus Cyphoderia, and therefore most likely the Euglyphida as a whole is much higher than currently recognised.

\section{Conclusions}

The results of this study provide the first insights into phylogenetic relationships between freshwater and marine supralittoral species. In our phylogenies, transitions between marine supralittoral and freshwater habitats occur only once or twice within the Cyphoderia genus.

Although our phylogenies do not include all described species, morphological-based taxonomy suggests only a small number of additional transitions within the Cyphoderiidae but none within the exclusively freshwater Trinematidae, Assulinidae and Euglyphidae clades, which comprise the majority of the known euglyphid species.

This reinforces the hypothesis that transitions of microeukaryotes are infrequent between truly marine (s. str. or supralittoral) and freshwater environments (or vice versa) and shows that the Euglyphida offer a valuable system for studying marine-freshwater transitions.

\section{Acknowledgments}

This work was funded by Swiss NSF projects no. 205321109709/1, PBELP2-122999 and IB73A0-111064/1 (SCOPES), 1120.08 (Ambizione fellowship, E. Lara) and the National Science and Engineering Research Council of Canada (NSERC 283091-09, B.S. Leander). The authors wish to thank Jackie Guiard and José Fahrni for technical support and helpful discussions. We thank Christophe Poupon for isolating some Cyphoderia specimens, Cédric Berney for SSU rDNA alignment of eukaryote supergroups and Tanja Schwander, Fabien Burki, Ralf Meisterfeld and David Wilkinson for fruitful discussions. We also thank Barry Warner, Taro Asada and several members of the Leander lab for their help in the field. SEM at the EPFL was possible through the Interdisci- plinary Center for Electron Microscopy (EPFL). Additional funding to E.M. by CCES projects RECORD and BigLink is kindly acknowledged.

\section{Appendix A. Supplementary data}

Supplementary data associated with this article can be found, in the online version, at doi:10.1016/j.ympev.2009.11.023.

\section{References}

Adl, S.M. et al., 2005. The new higher level classification of eukaryotes with emphasis on the taxonomy of protists. J. Eukaryot. Microbiol. 52 (5), 399-451.

Alverson, A.J., Jansen, R.K., Theriot, E.C., 2007. Bridging the Rubicon: phylogenetic analysis reveals repeated colonizations of marine and fresh waters by thalassiosiroid diatoms. Mol. Phylogenet. Evol. 45 (1), 193-210.

Bass, D., Cavalier-Smith, T., 2004. Phylum-specific environmental DNA analysis reveals remarkably high global biodiversity of Cercozoa (Protozoa). Int. J. Syst. Evol. Microbiol. 54, 2393-2404.

Bass, D., Richards, T.A., Matthai, L., Marsh, V., Cavalier-Smith, T., 2007. DNA evidence for global dispersal and probable endemicity of protozoa. BMC Evol. Biol. 7, 162

Berney, C., Pawlowski, J., 2004. How many novel eukaryotic 'kingdoms'? Pitfalls and limitations of environmental DNA surveys. BMC Biol. 2, 13.

Beszteri, B., Acs, E., Medlin, L.K., 2005. Ribosomal DNA sequence variation among sympatric strains of the Cyclotella meneghiniana complex (Bacillariophyceae) reveals cryptic diversity. Protist 156 (3), 317-333.

Booth, R.K., Sullivan, M.E., Sousa, V.A., 2008. Ecology of testate amoebae in a North Carolina pocosin and their potential use as environmental and paleoenvironmental indicators. Ecoscience 15 (2), 277-289.

Cavalier-Smith, T., 2009. Megaphylogeny, cell body plans, adaptive zones: causes and timing of eukaryote basal radiations. J. Eukaryot. Microbiol. 56 (1), 26-33.

Cavalier-Smith, T., von der Heyden, S., 2007. Molecular phylogeny, scale evolution and taxonomy of centrohelid heliozoa. Mol. Phylogenet. Evol. 44 (3), 11861203.

Chardez, D., 1991. The Genus Cyphoderia Schlumberger, 1845 (Protozoa, Rhizopoda, Testacea). Acta Protozool. 30 (1), 49-53.

Chomczynski, P., Sacchi, N., 1987. Single-step method of RNA isolation by acid guanidinium thiocyanate phenol-chloroform extraction. Anal. Biochem. 162 (1), 156-159.

Cuvelier, M.L., Ortiz, A., Kim, E., Moehlig, H., Richardson, D.E., Heidelberg, J.F., Archibald, J.M., Worden, A.Z., 2008. Widespread distribution of a unique marine protistan lineage. Environ. Microbiol. 10 (6), 1621-1634.

Darling, K.F., Wade, C.A., 2008. The genetic diversity of planktic foraminifera and the global distribution of ribosomal RNA genotypes. Mar. Micropaleontol. 67 (3-4), 216-238.

de Vargas, C., Norris, R., Zaninetti, L., Gibb, S.W., Pawlowski, J., 1999. Molecular evidence of cryptic speciation in planktonic foraminifers and their relation to oceanic provinces. Proc. Natl. Acad. Sci. USA 96, 2864-2868.

Epstein, S., Lopez-Garcia, P., 2008. "Missing" protists: a molecular prospective. Biodivers. Conserv. 17 (2), 261-276.

Fallu, M.A., Pienitz, R., 1999. Lacustrine diatoms in the Hudson Bay and James Bay area of Quebec - reconstruction of dissolved organic carbon concentrations. Ecoscience 6 (4), 603-620.

Finlay, B.J., Esteban, G.F., Brown, S., Fenchel, T., Hoef-Emden, K., 2006. Multiple cosmopolitan ecotypes within a microbial eukaryote morphospecies. Protist 157 (4), 377-390.

Golemansky, V., 1970. Rhizopodes nouveaux du psammal littoral de la Mer Noire (Note préliminaire). Protistologica 6 (4), 365-371.

Golemansky, V., 1973. Messemvriella filosa n. gen. n. sp. - une nouvelle thécamoebienne psammobionte (Rhizopoda: Testacea) des eaux souterraines littorales de la Mer Noire. Zool. Anzeig. 190 (5/6), 302-304.

Golemansky, V., 1974. Sur la composition et la distribution horizontale de l'association thécamoebienne (Rhizopoda, Testacea) des eaux souterraines littorales de la Mer Noire en Bulgarie. Bull. Inst. Zool. Musée XL, 195-202.

Golemansky, V., 2007. Testate amoebas and monothalamous Foraminifera (Protozoa) from the Bulgarian Black Sea coast. In: Fet, V., Popov, A. (Eds.), Biogeography and Ecology of Bulgaria. Springer Netherlands, pp. 555-570.

Golemansky, V.G., Todorov, M.T., 1999. First report of the interstitial testate amoebae (Protozoa: Testacea) in the marine supralittoral of the Livingston island (the Antarctic). Bulg. Antarct. Res. Life Sci. 2, 43-47.

Golemansky, V., Todorov, M., 2004. Shell morphology, biometry and distribution of some marine interstitial testate amoebae (Sarcodina: Rhizopoda). Acta Protozool. 43, 147-162.

Golemansky, V., Todorov, M., 2006. New data to the shell ultrastructure and the biometry of the marine interstitial testate amoebae (Rhizopoda: Testaceafilosia). Acta Protozool. 45 (3), 301-312.

Hall, T.A., 1999. BioEdit: a user-friendly biological sequence alignment editor and analysis program for Windows 95/98/NT. Nucleic Acids Symp. 41, 95-98.

Hannah, F., Rogerson, A., Anderson, O.R., 1996. A description of Paulinella indentata n. sp. (Filosea: Euglyphina) from subtidal coastal benthic sediments. J. Eukaryot. Microbiol. 43 (1), 1-4.

Huelsenbeck, J.P., Ronquist, F., 2001. MRBAYES: Bayesian inference of phylogenetic trees. Bioinformatics 17 (8), 754-755. 
Judge, M.L., Duell, R., Burriesci, L., Moarsi, W., 2009. Life in the supralittoral fringe: microhabitat choice, mobility and growth in the tropical Perwinkle Cenchritis (=Tectarius) muricatus (Linneaus, 1758). J. Exp. Mar. Biol. Ecol. 369 (2), 148-154.

Koch, T.A., Ekelund, F., 2005. Strains of the heterotrophic flagellate Bodo designis from different environments vary considerably with respect to salinity preference and SSU rRNA gene composition. Protist 156 (1), 97-112.

Lara, E., Heger, T.J., Mitchell, E.A.D., Meisterfeld, R., Ekelund, F., 2007. SSU rRNA reveals a sequential increase in shell complexity among the euglyphid testate amoebae (Rhizaria: Euglyphida). Protist 158 (2), 229-237.

Lara, E., Moreira, D., Vereshchaka, A., Lopez-Garcia, P., 2009. Pan-oceanic distribution of new highly diverse clades of deep-sea diplonemids. Environ. Microbiol. 11 (1), 47-55.

Lee, C.E., Bell, M.A., 1999. Causes and consequences of recent freshwater invasions by saltwater animals. Trends Ecol. Evol. 14 (7), 284-288.

Logares, R., Shalchian-Tabrizi, K., Boltovskoy, A., Rengefors, K., 2007. Extensive dinoflagellate phylogenies indicate infrequent marine-freshwater transitions. Mol. Phylogenet. Evol. 45 (3), 887-903.

Logares, R., Brate, J., Bertilsson, S., Clasen, J.L., Shalchian-Tabrizi, K., Rengefors, K., 2009. Infrequent marine-freshwater transitions in the microbial world. Trends Microbiol. 17 (9), 414-422.

Meisterfeld, R., 2002. Testate amoebae with filopodia. In: Lee, J.J., Leedale, G.F., Bradbury, P. (Eds.), The Illustrated Guide to the Protozoa. Society of protozoologists, Lawrence, Kansas, USA, pp. 1054-1084.

Nicholls, K.H., 2003a. Corythionella golemanskyi sp. n.: a new freshwater, filose, testate rhizopod. Acta Protozool. 42 (1), 75-80.

Nicholls, K.H., 2003b. Form variation in Campascus minutus and a description of Campascus simcoei sp. n. (Testaceafilosea, Psammonobiotidae). Eur. J. Protistol. 39 (1), 103-112.

Nicholls, K.H., 2005. Psammonobiotus dziwnowi and Corythionella georgiana, two new freshwater sand-dwelling testate amoebae (Rhizopoda: Filosea). Acta Protozool. 44 (3), 271-278.

Nicholls, K.H., 2007. Descriptions of two new marine species of the sand-dwelling testacean genus Corythionella: C. gwaii sp. n. and C. rachelcarsoni sp. n., and a revised description of $C$. acolla gol. (Rhizopoda: Filosea, or Rhizaria: Cercozoa). Acta Protozool. 46 (3), 269-278.

Nicholls, K.H., 2009. A multivariate statistical evaluation of the "acolla-complex" of Corythionella species, including a description of C. darwini n. sp. (Rhizopoda: Filosea or Rhizaria: Cercozoa). Eur. J. Protistol. 45 (3), 183-192.

Nylander, J.A.A., 2004. MrAIC.pl. Program Distributed by the Author. Evolutionary Biology Centre, Uppsala University.

Ogden, C.G., Couteaux, M.M., 1989. Interstitial marine rhizopods (Protozoa) from littoral sands on the East Coast of England. Eur. J. Protistol. 24 (3), 281-290.

Pankow, H., 1982. Paulinella chromatophora Lauterb, a Testacea till now only observed in fresh-water habitats, from the shallow bays of the Darss and Zingst (Southern Baltic Sea). Arch. Protistenk. 126 (3), 261-263.
Pawlowski, J., Holzmann, M., 2002. Molecular phylogeny of Foraminifera - a review. Eur. J. Protistol. 38 (1), 1-10.

Scheckenbach, F., Wylezich, C., Mylnikov, A.P., Weitere, M., Arndt, H., 2006 Molecular comparisons of freshwater and marine isolates of the same morphospecies of heterotrophic flagellates. Appl. Environ. Microbiol. 72 (10), 6638-6643.

Schönborn, W., 1965. Die sedimentbewohnenden Testaceen einiger Masurischer Seen. Acta Protozool. 3 (27), 297-308.

Shalchian-Tabrizi, K., Brate, J., Logares, R., Klaveness, D., Berney, C., Jakobsen, K.S., 2008. Diversification of unicellular eukaryotes: cryptomonad colonizations of marine and fresh waters inferred from revised 18S rRNA phylogeny. Environ. Microbiol. 10 (10), 2635-2644.

Stamatakis, A., Hoover, P., Rougemont, J., 2008. A rapid bootstrap algorithm for the RAxML web servers. Syst. Biol. 57 (5), 758-771.

Todorov, M., Golemansky, V., 2007. Seasonal dynamics of the diversity and abundance of the marine interstitial testate amoebae (Rhizopoda: Testacealobosia and Testaceafilosia) in the Black Sea supralittoral. Acta Protozool. 46 (2), 169-181.

Todorov, M., Golemansky, V., Mitchell, E.A.D., Heger, T.J., 2009. Morphology, biometry and taxonomy of freshwater and marine interstitial Cyphoderia (Cercozoa: Euglyphida). J. Eukaryot. Microbiol. 56 (3), 279-289.

Valkanov, A., 1970. Beitrag zur Kenntnis der Protozoen des Schwarzen Meeres. Sonderdruck Zool. Anzeig. 184, 241-290.

Van de Peer, Y., De Rijk, P., Wuyts, J., Winkelmans, T., De Wachter, R., 2000. The European small subunit ribosomal RNA database. Nucleic Acids Res. 28 (1) $175-176$.

Von der Heyden, S., Cavalier-Smith, T., 2005. Culturing and environmental DNA sequencing uncover hidden kinetoplastid biodiversity and a major marine clade within ancestrally freshwater Neobodo designis. Int. J. Syst. Evol. Microbiol. 55, $2605-2621$.

Vørs, N., 1993. Marine heterotrophic amebas, flagellates and heliozoa from Belize (Central-America) and Tenerife (Canary-Islands), with descriptions of new species, Luffisphaera bulbochaete n. sp., L. longihastis n. sp, L. Turriformis n. sp., and Paulinella intermedia n. sp.. J. Eukaryot. Microbiol. 40 (3), 272-287.

Wailes, G.H., 1927. Rhizopoda and Heliozoa from British Columbia. Ann. Mag. Natl. Hist. 20 (9), 153-156.

Wulff, A., 1916. Über das Kleinplankton der Barentssee. Wiss. Meeresunters. Abt. Helgoland 13, 95-118.

Wylezich, C., Meisterfeld, R., Meisterfeld, S., Schlegel, M., 2002. Phylogenetic analyses of small subunit ribosomal RNA coding regions reveal a monophyletic lineage of euglyphid testate amoebae (order Euglyphida). J. Eukaryot. Microbiol. 49 (2), 108-118.

Yoon, H.S., Nakayama, T., Reyes-Prieto, A., Andersen, R.A., Boo, S.M., Ishida, K., Bhattacharya, D., 2009. A single origin of the photosynthetic organelle in different Paulinella lineages. BMC Evol. Biol. 9. 